\title{
PROZA KU CZCI M. B. WNIEBOWZIETEJ Z 14 W.
}

Kult Matki Bożej szerzył się w Polsce od chwili przyjęcia chrześcijaństwa przez naszych przodków, jak tego dowiódł ks. Fijałek w swym cennym studium: „Królowa Korony Polskiej. Historia kultu Matki Boskiej w Polsce średniowiecznej w zarysie“ "). "Cześć Maryi pisze autor - wyrosła $w$ Polsce $z$ pierwszego $w$ niej posiewu religii chrześcijańskiej przez mnichów zakonu św. Benedykta $w$ drugiej polowie wieku dziesiątego". A ponieważ wówczas szczególnie czczono Matkę Bożą jako wniebowziętą, bo święto jej Wniebowzięcia jako nowe i wyraźnie uwydatniające jej chwałe przyciągało na siebie uwage teologów i wiernych więcej od innych świąt maryjnych, ku czci Wniebowziętej powstają kościoły i kaplice a pierwsza katedra metropolitalna na ziemiach polskich w Gnieźnie otrzymała tytul: Assumptionis $B M V$, który nosi po dzień dzisiejszy. „Za sprawą prawdziwego szer. mierza Chrystusa, króla Bolesława zw. Chrobrym, ... bazylika gnieźnieńska pold wezwaniem Wniebowzięcia Panny uwielbionej stała się w roku tysiącznym głową i macierzą wszystkich w Polsce kościołów" pisze ten sam autor ${ }^{2}$ ). Tak samo 400 lat później druga katedra metropolitalna we Lwowie zostaje przez ancybiskupa bł. Jakuba Strep๕̨ oddana pod opiekę M. B. wniebowziętej (w r. 1404).

Kult Wniebowziętej wzrastał u nas $\mathrm{z}$ każdym wiekiem. Liczne powstawały fundacje kolegiów mansjonarzy, których obowiązkiem było śpiewanie officium i odprawianie mszy św. wotywnej o Matce Bożej, najpierw w XIV wieku w Krakowie i Płocku, a później we wszystkich kościołach kolegiackich i wielu parafialnych. "W takiej liczbie jak w Polsce nie spotyka ich się nigdzie w kościele lacińskim, chyba tylko we Wloszech; posiadał je każdy znaczniejszy kościół pod wezwaniem Wniebowzięcia N. M. Panny z osobną zazwyczaj kaplicą, w której śpiewano uroczyście kurs całodobny wraz ze mszą św. o Błogosławionej". "Tajemnicę Wniebowzięcia i chwałę Róży niebieskiej przekazali potomnym biskupi krakowscy owych wieków w obszernych teologicznych arengach swoich dyplomatów. $Z$ tego również czasu pochodzące a najstarsze w Polsce bractwa, bądź mieszczańskie( szczególniej t. zw. literackie), do których się wpisywali także i królowie,

1) Por. Przegląd Kościelny I (Poznań 1902), str. 409-418, II, 108 nu.; 225 nn.; III (1903) 23 n.n.; $81 \mathrm{nn}$.

-) Tamże str. 409. 
bądź kapłanów świeckich, noszą tytuł i szerzą cześć Wniebowzięcia Panny chwalebnej" "3).

Z XIV wieku pochodzi także najstarszy utwór poetycki, ułożony przez Polaka ku czci Matki Bożej Wniebowziętej. Jest nim s e k w e nc j a, czyli jak wówczas mówiono p r o z a Salve salutis janua, ułożona za czasów króla Kazimierza Wielkiego przez biskupa poznańskiego J a n a $z$ Kempy, herbu Łodzia, zmarłego w roku 1346. Wspominają o niej i o biskupie Janie jako autorze tak Rocznik Włocławski ${ }^{4}$ ), jak i Długosz w katalogu biskupów poznańskich ${ }^{5}$ ), gdzie czytamy: Iohannes de.Kampa ... vivens ... singulariter Virgini, Mariae famulabatur: unde et in illius honorem prosas compilavit: unam de Assumptione quae incipit ,Salve salutis ianua“, aliam de Purificalione ... Sekwencje te odnaleziono $\mathrm{w}$ mszale krakowskim $\mathrm{z} X \mathrm{XV}$ wieku ${ }^{6}$ ), a opublikował ją w r. 1891 jezuita Dreves w "Analecta hymnica" "). Znajduje się ona także $\mathrm{w}$ mszale poznańskim z $\mathrm{r}$. $1524^{8}$ ) i w sekwencjarzu opactwa w St. Gallen ${ }^{9}$ ).

3) Tamże str. 414 .

4) Por. Monumenta Poloniae historica II, str. 945.

: Por. D ł u gosz, Opera omnia I, str. 499.

c) Rękopis znajdujący się w kapitúlarzu krakowskim a noszący numer 6; sekwencja znajduje się w dodatku na 4 stronie od końca (bez nut).

7) Analecta hymnica medii aevi. T. X: Liturgische Prosen des Mittelalters (Leipzig 1891), str. $84 \mathrm{n}$.

$\left.{ }^{8}\right)$ Wspomniał już o niej Ks. Hoz a k ow s k i w dziele: Wykład mszy św., Poznań 1914, str. 63. Dzięki uprzejmości Ks. Kan. Jó z ef a No wa c k i e go dowiedzjałem się, że mszal ten nadal znajduje się w Archiwum Kapitulnym poznańskim. Tekst sekwencji, pordanej w officia propria sanctorum, fol. 5455, w kilku miejscach odbiega od tekstu krakowskiego. Mszał drukowany jest w Krakowie u Hallera r. 1524.

$\left.{ }^{9}\right)$ Tak podaje Jachimecki, Muzyka polska w rozwoju historycznym I (Kraków 1948), str. 36: „Przytaczają tę sekwencję także obce księgi liturgiczne, między innymi sekwencjarz opactwa w St. Gallen w Szwajcarii rkp. 546, gdzie jako autora melodii zanotowano: melodia vero est patris Longi Johannis presbyteri nostri cenobii. Jest ona identyczna $z$ melodią $w$ mszale wawelskiej katedry, a służyła również. do innych sekwencji, np. do Salve mater Salvatoris, którą zapisano we wspomianym rękopisie „L a u da Sion“ Biblioteki OO. Dominikanów w Krakowie. W St. Gallen uważańo ją za ,p u lc he r rim a e t d evo ta“. Jachimecki wspomina również o mszale wawelskim, w którym by byla sekwencja wraz z nutami. Takiego mszalu obecnie Wawel nie posiada.

Już w czasie druku artykułu nadeszla odpowiedź $z$ Bibliorteki $w$ St. Gallen, że kodeks nr. 546 pochodzil z roku 1507, jest więc późniejszy od ręko- 
Średniowiecze lubowało się w takich "prozach", t. j. tekstach podkładanych pod nuty alleluja, kończącego graduale we mszy, św. Ta melodia była główną rzeczą a tekst dodatkowa, a wobec tego łatwo zrozumieć, że dopiero z czasem teksty nabierały piękniejszej i doskonalszej formy rytmicznej. W mszale krakowskim mamy kilka sekwencji ku czci M. B. Wniebowziętej, sekwencja Salve salutis ianua umieszczona jest przy końcu jako dodatek a nie przy formularzu mszy św. na 15 sierpnia, z czego wynika, że jej rzadziej używano, raczej ad libitum.

Stroną muzyczną prozy zajął sie swego czasu znany badacz hi-

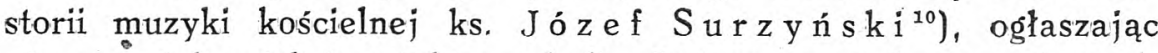
równocześnie $z$ tekstem także melodię. Jest rzeczą godną uwagi, że na akademii urządzonej ku uczczeniu dogmatyzacji Wniebowzięcia M.B., chór seminarium duchownego w Sandomierzu, odśpiewał tę właśnie proze według dawnej melodii, a stało się to dzięri inicjatywie wybitnego znawcy dawnej muzyki kościelnej ks. W. Swierczka C. M. ${ }^{11}$ ).

Stroną językową naszej prastarej sekwencji zajmował się twórca historii hymnologii polskiej, zmarły w więzieniu niemieckim ks. B r o$\mathrm{n}$ is $ł$ a w G 1 adysz, konstatując, że autorem jej jest niewątpliwie biskup Jan. Charakteryzując wersyfikację utworu ${ }^{12}$ ), słusznie zaznacza autor, że rytmika nie zawsze poprawna, ale czy ta nieprawidłowość rytmu nie jest raczej spowodowana melodia, do której poeta

pisu krakowskiego. Wobec tego autorstwo biskupa Jana nie ulega wątpliwości. Tekst z St. Gallen w dwóch miejscach różni się od tekstu krałkowskiego. Rozpowszechnienie sekwencji należy nie tekstowi, ale melodii przypisać, która ogólnie się podobała. Czy melodia jest utworem wzmiankowainego „Johannes Longus“, któremu ją kodeks przypisuje, jest zdaniem kustosza Biblioteki dr Dufta dość wątpliwe. Zostaje przeto możliwość, że autorem melodii jest również biskup Jan.

10) Matka Boska w muzyce polskiej, Kraków 1905; jest to odbitka rozprawy umieszczonej w „Księdze pamiątkowej maryjańskiej“ I (Lwów 1905) str. 163. Czytamy tam: „Muzyka jednogłosowa prozy tej napisana jest artystycznie wedle prawideł, jakiemi w XIV wieku przy układaniu sekwencyj w kościele katolickim się rządzono, składa się z 16 zwrotek a z ośmiu rozzmaitych melodyj w transponowanej o kwartę wyżej tonacji jońskiej. Dwie po sobie następujące zwrotki mają tęż samą melodyę“. Por. też artykul Prof. Jachimecki e g o, pt. Sredniowieczne zabytki Pol. Kultury Muzycznej, w: „Muzyce Kościelnej“, rok V (1950) str. 108 n.

11) Por. Kronikę Diecezji Sandomierskiej 1951 nr. 1, str. 50.

${ }^{12}$ ) Por. art. „Lacińskie sekwencje mszalne z polskich źródeł średniowiecznych“w „Ateneum Kapłańskim“ 1934, str. 105-119. 
dobierał słowa, aniżeli brakiem talentu poetyckiego? Natomiast rym jest prawie wszędzie bez zarzutu, poeta przedkłada rym nad rytm, używa i rymu trzyzgłoskowego, używa go nawet i nadmiernie, chociaż przyznać trzeba, że to są najczęściej rymy mniej doskonałe, gramatyczne, co znów nie jest tak bardzo dziwne, bo rymotwónstwo wówczas dopiero się rozwijało.

Oto tekst sekwencji i jej przekład, w którym częściowo naśladowano rytm i rymy oryginału, umyślnie częściowo tylko, bo dokładne naśladownictwo spowodowałoby zbyt wielkie odbieganie od tekstu i zatarłoby myśli oryginalne autora:

Salve, salutis janua,

Solemnitas annua

Tibi celebratur,

Flosculus sanctitatis;

Dies solemnitatis, Per te iteratur.

Cum jam sis assumpta,

Resumpta

Ad coeli palatia,

Jam rimaris cuncta

Conjuncta

Semota fallacia.

Natus decoravit,

Ornavit,

Sic ipsam disposuit.

Ut coeli reginam,

Dominam

In throno suo posuit.

Quidam ipsam dubitant,

Asserere haesitant

Corpore assumptam.

Sed est incredibile,

Immo impossibile

In terra sepultam.

Cum sit thronus regius,

Thalamus egregius,

In quem rex declinavit.

Cur corrumpi debuit,

Quae domum Deo praebuit

In qua se humanavit.

Corpus gloriosum

Multumque formosum

Nullo modo putruit,

Regis angelorum, 
Domini coelorum

Quod hospitium fuit.

Absit, ut hoc credam

quod pars sit putrida quaedam,

Ventris virginei,

quae manet (in?) aula Dei.

Ipsam deprecemur,

Ut ibi locemur

Cum ipsius nato,

Ubi regnat vere,

Nos velit fovere

In regno beato.

\section{Przekład:}

O bramo zbawienia,

witaj, ku twej chwale

święto urządzamy.

O kwiecie świętości, obchód ten coroczny

tobie zawdzięczamy.

Tyś do nieba wzięta,

znowuś tam przyjęta,

do niebieskich włości.

Wszak tam już oglądasz

wszystko, czego żądasz.

prócz wszech znikomości.

Syn cię czcią obdarzył,

hojnie wyposażyl,

i tak ciebie wslawil:

Jako nieb Królową,

jako Pania nowa

na tronie posadził.

Niektórzy w to wątpią,

przyjąć się wahają,

żeś do nieba wzięta.

Lecz byś w ziemi byla, uwierzyć nie sposób,

rzecz to niepojęta!

Boś ty króla tronem,

Komnatą w:paniałą, w której spocząć raczył.

Jakże ma gnic w grobie

ta, w które! On lenie

ziemski byt swój począl?

Ciało przechwalebne

i wielce dostojne 


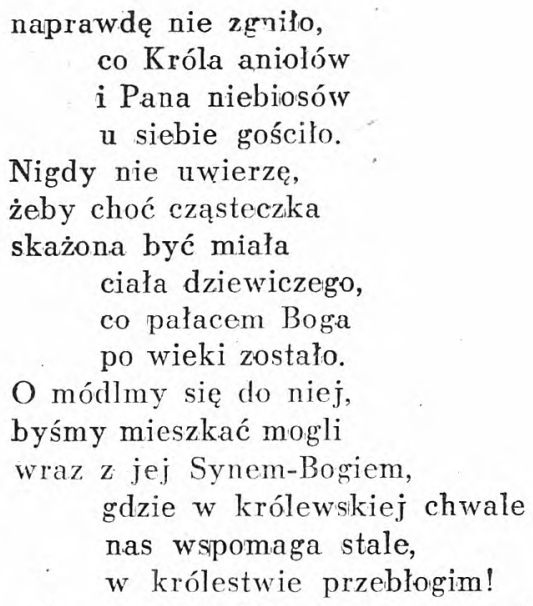

Utwór pociąga swoją prostotą. Nie ma w nim ani przesadnych porównań ani uczonych wywodów, jest on jasnym wypowiedzeniem się duszy ,wierzacej w Wniebowzięcie Matki Bożej i ufaiacej jej opiece, jest on wyraźnym dowodem na prawdziwość słów Długoszowych, że biskup Jan „w szczególny sposób służył Pannie Marii!".

Jest $\mathrm{w}$ prozie wzmianka, że niektórzy nie uznają Wniebowzięcia Marii, więc powstaje pytanie, $\mathrm{z}$ kim tı poeta polemizuje. Czy w Polsce $w$ owym wieku toczyły sie spory naukowe na ten temat? Jest to bardzo wątpliwe. Także w innych krajach nie słychać już w XIV wieku o poważniejszych czy częstszych dysputach. Raczej przypuszczam, że autor nawiązuje do lekcji brewiarzowej na dzień Wniebowzięcia, dość często używanej w jutrzni aź do reformy Piusa V. Zanim bowiem wciągnięto $w$ officium dzisiejsze lekcje św. Jana Damasceńskiego, czytano ustępy $z$ listu "C og it is m e", przypisywanego św. Hieronimowi a prawdopodobnie ułożonego przez Paschasiusa Radberta ( $\dagger$ 860), a tam czytamy: ${ }^{18}$ ) Multi nostrorum dubitant, utrum assumpta fuerit simul cum corpore an abierit corpore relicto. Quomodo autem vel quo tempore aut a quibus personis sanctissimum corpus eius inde ablatum fuerit vel ubi transpositum, utrumne resurrexit, nescitur, quamvis nonnulli astruere velint eam iam resuscitatam et beata cum Christo immortalitate in coelestibus vestiri. Podobieństwo obu tekstów jest całkiem wyraźne. Zrozumiałe teraz także się staje podkreślenie przez poete, że Maria „z ciałem" została do nieba wzięta, bo tẹ myśl właśnie porusza traktat pseudohieronimowy. Wątpliwości podobne mogło ów-

13) Mign e, Patrologia Latina 30, str. 123. 
czesnym także podsuwać martyrologium benedyktyńskie Usuarda ( $\mathrm{z}$ r. 860), bardzo rozpowszechnione, w którym święto $M$. B. Wniebowziętej jest umieszczone, ale z dodatkiem: Quo illud Spiritus

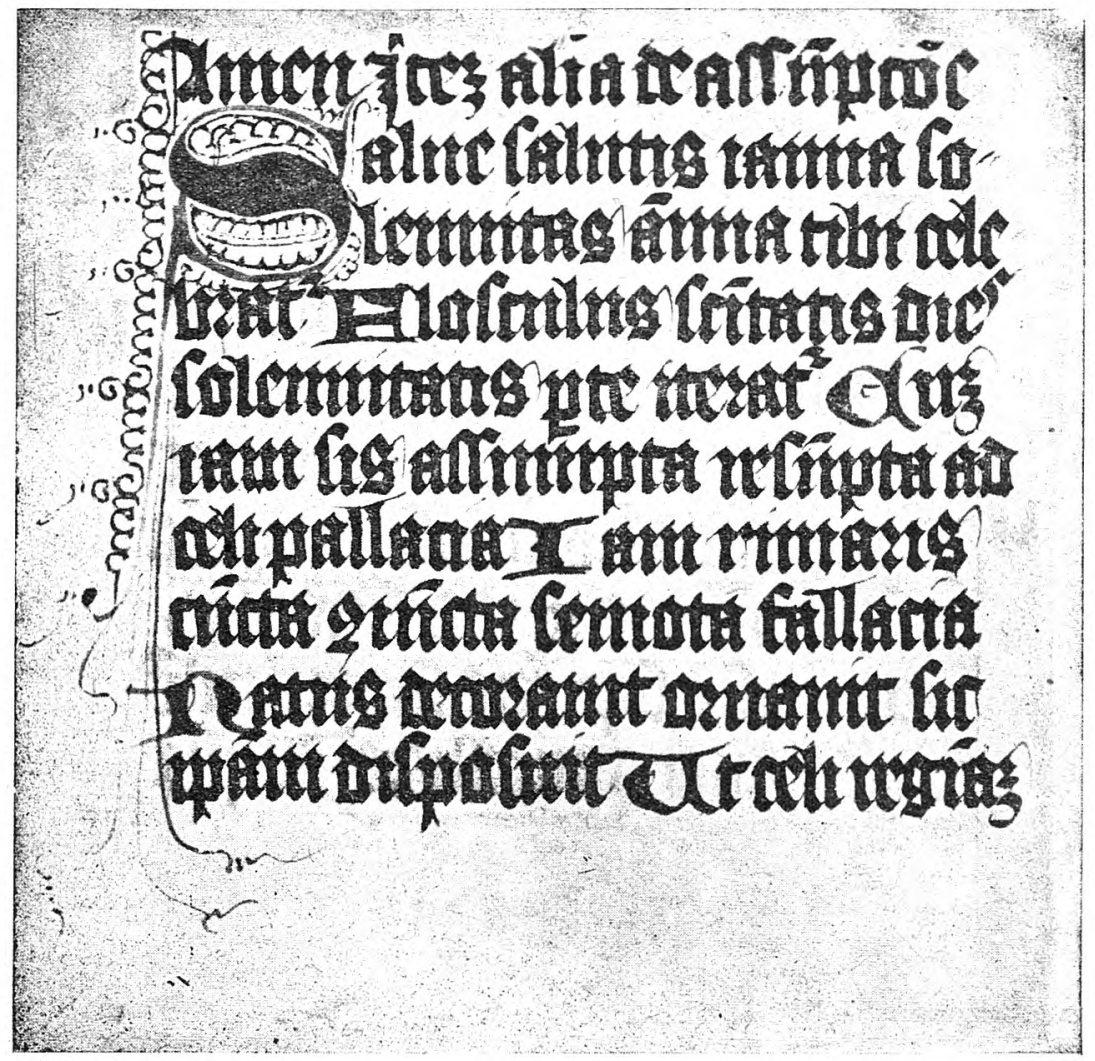

Sekwencja Salve salutis ianua z mszału krakowskiego (XV w.)

Sancti templum nutu et consilio divino occultatum sit, plus elegit sobrietas Ecclesiae nescire quam aliquod frivolum et apocryphum inde tenendo docere ${ }^{14}$ ).

14) Mign e, P.L. 124, 365. Por. té̇ uwagi w pracy J: Ernist'a: Die leibliche Himmelfahrt Mariae, Regensburg 1921, str. 42. Enn st przypisuje list pseudo-hieronimowy św. Ambrożemu Autpertowi OSB († 778). Także początek hymnu zdradza pewne podobieńsitwo do tekstu listu: „die tantae solemnitatis..." per singulos annos „... gaudio celebretur“: 


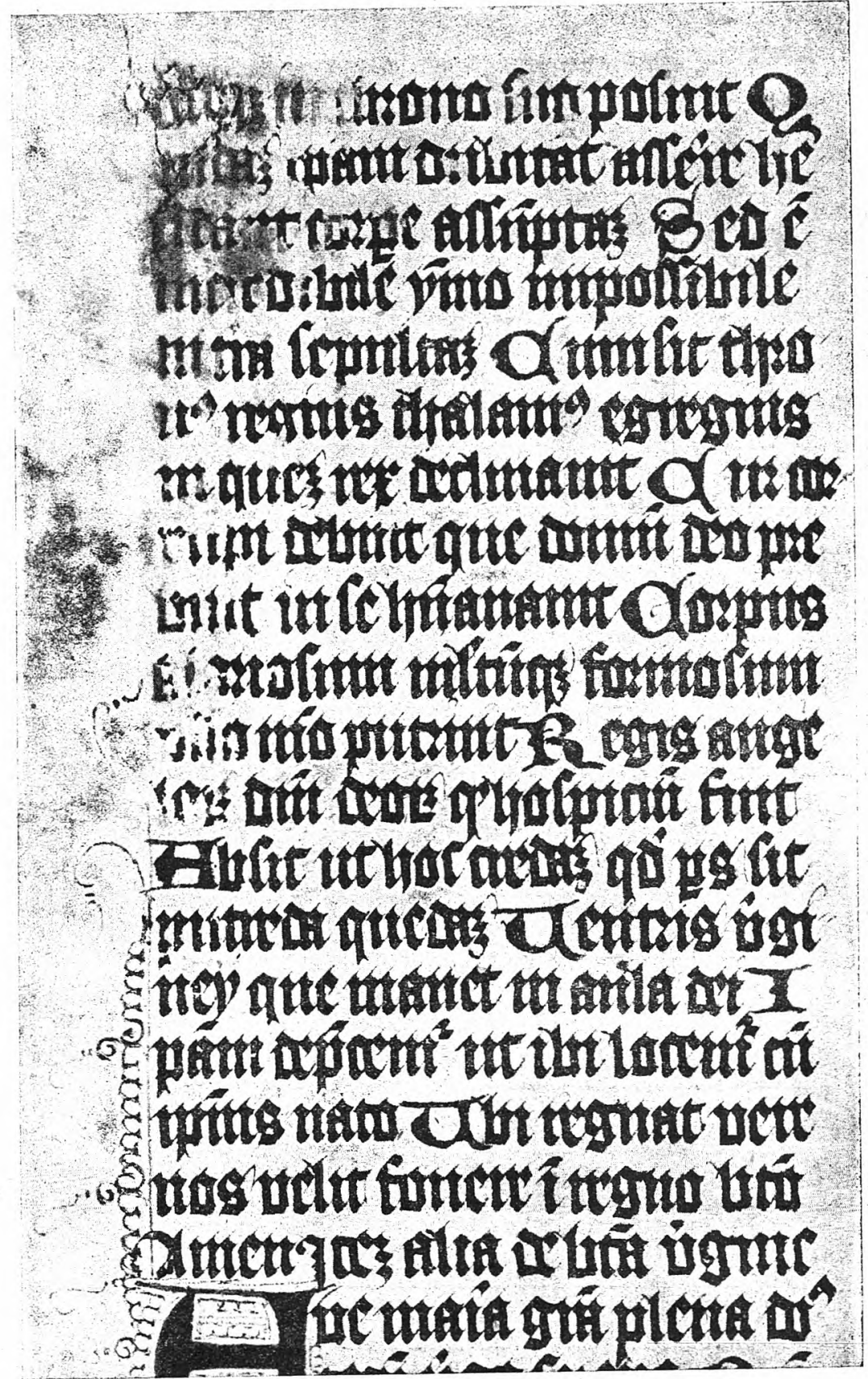

Sekwencja Salve salutis ianua z mszału krakowskiego (XV w.) 
$T_{y m}$ watpliwościom przeciwstawił biskup $J$ an wiarę swoją $i$ wiarę ludu polskiego z XIV wieku, że jest rzeczą niemożliwą, nie do uwierzenia ${ }^{15}$ ), by Maria była w ziemi pogrzebana, i jej jako Królowej niebios wierszem swoim złożył hołd godny. Właśnie dlatego, że te wątpliwości były mu znane, tym jaśniej wynika, jak silna była wiara dusz polskich w fakt Wniebowzięcia.

Proza Salve salutis ianua stanowi obok nieco starszej pieśni Bogu Rodzica początek naszej poezji maryjnej.

Kraków

Ks, ALERSY KLAWEK

\section{POWSTANIE I ROZWÓJ LITANII DO NAJŚW. MARII PANNY}

Modiitwa litanijna znana jest w kościele już od pierwszego wieku ery chrześcijańskiej, zaś początkami swoimi sięga daleko w historię Starego Testamentu. Odmawiano ją zwykle przed rozpoczęciem Najśw. Ofiary. Przeważnie diakon odczytywał donośnym głosem inwokacje, na które wierni odpowiadali chórem: Kyrie eleison, te rogamus audi nos". Około V w. znane już były w kościele litanie, odmawiane prywatnie, bez łączenia ich ze Mszą św. Powstały one w Rzymie, skąd pobożność chrześcijańska rozniosła je po całym świecie katolickim. Były to przede wszystkim litanie do Wszystkich Świętych. Pierwsze ślady litanii do N. Marii Panny spotykamy dopiero w XII $\mathrm{w}^{1}{ }^{1}$ ) Modlitewnik św. Elżbiety z Schönau zawiera szereg elogii, pisanych na cześć N. Marii Panny, których tytuły weszły później do litanii maryjnych, np.: ave Mater gratiae, ave Mater misericordiae, Refugium miserorum, Creatoris sanctissima Mater, Sancta Dei genitrix, itp. W XV w. była już znana większa liczba litanii maryjnych, pisanych przeważnie po łacinie.

Św. Kongregacja Obrzędów dekretem z dnia 6. II. 1894 orzekła, że publicznie mogá być odmawiane tylko te litanie, które na mocy bulli papieża Klemensa VIII znajdują się w brewiarzu i w późniejszych wydaniach Rytuału Rzymskiego, zatwierdzonego przez Stolicę

15) Tekst poznański mniej stanowczo się wyraża: sed est displicibile, immo indicibile in terra sepultam.

1) W. Schleussner, Zur Entstehung der lauretanischen Litanei, w Tüb. Theol. Quartalschrift 1926, s. 257 nn. 